\title{
ON THE GROWTH AND FEEDING OF THE LARVAL AND POST-LARVAL STAGES OF THE CLYDE HERRING
}

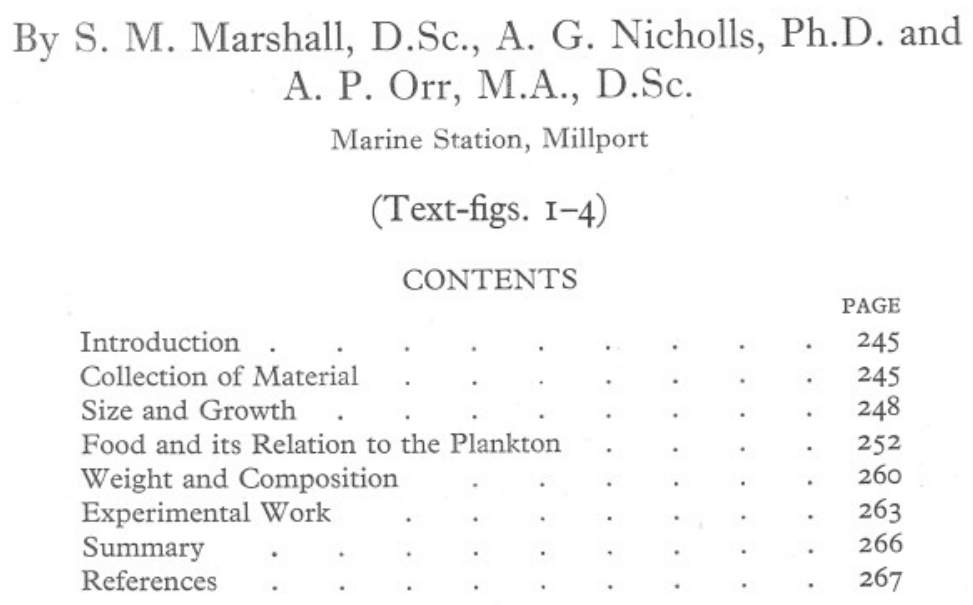

\section{INTRODUCTION}

The comparatively enclosed waters of the Clyde sea-area offer an opportunity of studying the biology of herring larvae from one spawning area.

The chief spawning here takes place in spring and there are two well known grounds, one on the Ballantrae Banks off the coast of south Ayrshire, and the second on the Iron Rock Ledges off the south-west coast of Arran (Fig. I). These grounds have long been known to Clyde fishermen, and "spawny" haddock have been recorded from both places by Clark (I933).

It was decided to follow the development of the eggs spawned on the Iron Rock Ledges because they are in a more sheltered position and are more accessible from the laboratory than the Ballantrae Banks. The intention was to take weekly samples of the larvae and to follow the changes in length, weight, chemical composition, and food and to correlate the last with changes in the plankton.

\section{Collection of Material}

Spawning usually takes place towards the end of February or early in March, and several attempts were made about that time to find the spawn by dredging. On March I9 I934 spawn was obtained on small boulders, pebbles and Laminaria at the Iron Rock Ledges. On the same date a few larvae, chiefly at the yolk-sac stage, were caught by townetting; thereafter the 


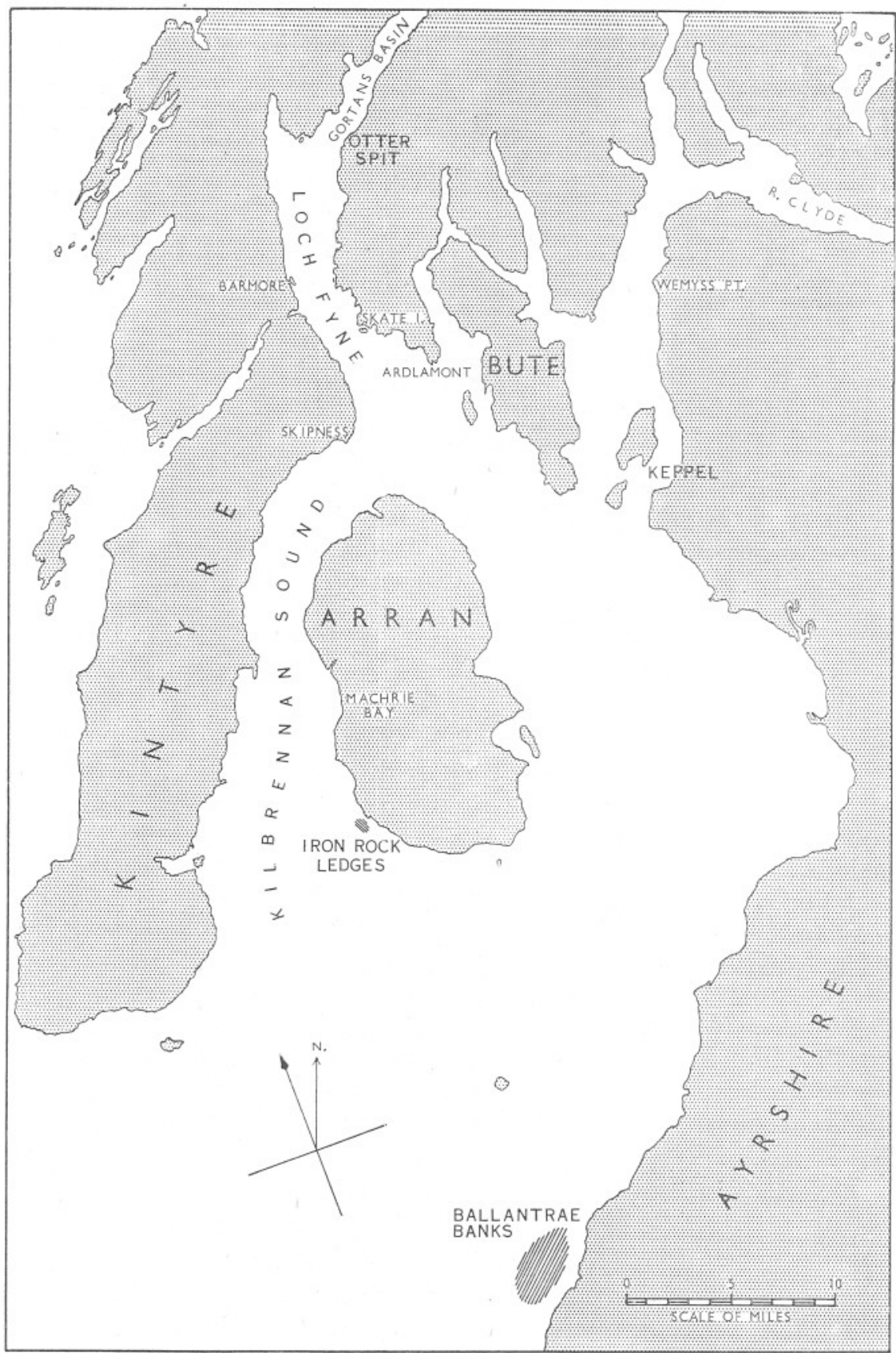

Fig. I. The Clyde sea-area, showing localities where young herring were found. Spawning grounds hatched. 
gradually developing larvae were captured at intervals of about a week until April 30. They appeared to move northwards, for after the first week or two more were caught in Machrie Bay, about 6 miles to the north, than at the Iron Rock Ledges. During and after April ctenophores and medusae became unusually abundant and killed the few larvae caught in the townettings. No herring were caught after April 30 in spite of an intensive search, and it is possible that the abundance of ctenophores and medusae was, at least in part, responsible for this. It is also possible, however, that had townettings been taken at night, as in the following year, they would have been more successful.

Larvae were obtained for a few days in townettings off Keppel Pier at the end of April and beginning of May, but these also disappeared.

Owing to the failure to obtain herring later than April in 1934 an effort was made the following year to complete the series up to metamorphosis. In I935 larvae were found on April 2. The catch consisted mainly of yolk-sac stages but, as might be expected from the slightly later date, there were also larger specimens up to $13 \mathrm{~mm}$. In the two following weeks larvae were taken in Machrie Bay, but in diminishing numbers, and by April I6 they had almost disappeared, just as in the previous year. In view of Russell's (I930) finding that larval clupeids were more readily obtained in the dark, hauls were taken the following week at night in the Kilbrennan Sound and the mouth of Loch Fyne and good catches were obtained off Skipness and Barmore Peninsula. The herring were therefore still moving north. Night hauls (between dusk and dawn) were continued and weekly samples taken until the beginning of June. During this time most were obtained at a position just south of the Otter Spit in Loch Fyne. This represents the limit of the northward migration for, although frequent hauls were taken in the Gortans Basin to the north of this, only a few herring were caught.

As in 1934 herring larvae were caught off Keppel Pier in large numbers at the end of April and beginning of May and these were later followed north and caught off Wemyss Point. Thus while the herring from the Iron Rock Ledges migrated in a northerly direction up the Kilbrennan Sound and reached the lower part of Loch Fyne, where they stayed till metamorphosis, it seems probable that the herring taken off Keppel Pier and Wemyss Point originated on the Ballantrae Banks and migrated in a similar direction along the east coast of the Firth of Clyde.

Until May 27 the net used was a two metre stramin adapted to a rectangular frame, but on this date the catches were very small and three days later a Poole Sprat Trawl with a stramin cod-end was used instead and proved successful. On June 5, however, the catch even with this net was very small and a few of the herring were metamorphosing. From this time onwards, apart from an occasional metamorphosed specimen, no herring were taken despite a thorough search, using the Poole Sprat Trawl in deep and shallow water and a finemeshed shore seine in many of the sandy bays of the area.

The larvae over the spawning ground were taken in mid-water or near the 
bottom ( $15 \mathrm{~m}$.) but may have been generally distributed. As they were followed northwards only hauls in deeper water $(20-40 \mathrm{~m}$.) were successful. These were daylight hauls and the larvae were soon lost. After night hauls were begun larvae were found near the surface, always above $5 \mathrm{~m}$. until May 7 , but as the time of metamorphosis approached they remained in deeper water. On May I4 the majority (about 1900 in a $15 \mathrm{~min}$. haul) were taken at $10 \mathrm{~m}$. whereas a surface haul produced under 20 . On May 21 and 30 the largest catches were at $20 \mathrm{~m}$., with very few either above or below. The few specimens obtained on June 5 were caught at various depths.

The results of the collections are summarized in Table I. Immediately on capture the herring, except those for chemical analysis, were fixed in $5 \%$ neutral formalin.

\section{Size AND GROWTH}

Our own observations, supplemented by the reports of the Fishery Officers of the Clyde District, enable us to fix with a certain degree of accuracy the date of hatching of the larvae. In I934, although some spawning was reported by the Fishery Officers as early as February 17 , the main spawning appears to have occurred at the Iron Rock Ledges during the week ending March IO. Spawn was dredged on March 19 and brought into the laboratory where at a temperature of about $7^{\circ} \mathrm{C}$. it was hatching by March 23. There were thus from $\mathrm{I} 3$ to 20 days between spawning and hatching. In the laboratory further samples of herring spawn had been artificially fertilized and at tank temperatures of about $7^{\circ} \mathrm{C}$. took about a fortnight to hatch. The temperature of the sea on the spawning ground at this time was only slightly if at all lower (March I3, $7.2^{\circ} \mathrm{C}$.; March $19,6.88^{\circ} \mathrm{C}$.), so that the period of development may be assumed to be between a fortnight and three weeks. Thus with spawning in the sea taking place between March 3 and Io, hatching may be assumed to have taken place chiefly between March I6 and 23.

The observations of Meyer (quoted by Williamson, I9I0) and Williamson (I9IO, I9I I) on the influence of temperature on the time of hatching of herring ova were made at temperatures either below or (in one case) above these. So far as our results can be compared with theirs they are in agreement.

In 1935 the Fishery Officers reported herring "mazy" at the Iron Rock Ledges during the week ending March 2 and "running" during the week ending March 9. Thus the date in 1935 is within a day or two of that in 1934 and sufficiently close for the 2 years' results to be considered together. It was impossible to confirm this date in 1935 as no hauls could be taken until April 2. It is assumed that the larvae caught on March I9 I934 were just hatched and that date has been taken as the zero point in both years on which to base the approximate age in days of the fish caught, as shown in Table I.

On each occasion that herring were taken, either the whole catch or a sample of it was measured. The results are shown in Table II and the median lengths are shown in Table I and Fig. 2. Measurements were made from the tip of 
the snout to the end of the tail, or to the tip of the dorsal fluke after that had developed. At the time of hatching the larvae measured about $7 \mathrm{~mm}$. and from then until metamorphosis, as shown by Fig. 2, there is a regular weekly increment of about $3 \mathrm{~mm}$. The points do not lie on a straight line but it is obvious that, apart from four points, a straight line expresses the relationship best. It is believed that the catches belonging to these four points are not truly representative of the main shoal. The sample taken on April 2 1935,

Table I. Herring Samples from Clyde Sea-Area, I934-35

\begin{tabular}{|c|c|c|c|c|c|c|c|}
\hline \multirow[b]{2}{*}{ Date } & \multirow[b]{2}{*}{ Place } & \multirow{2}{*}{$\begin{array}{l}\text { Approxi- } \\
\text { mate age } \\
\text { in days } \\
\text { after } \\
\text { hatching }\end{array}$} & \multirow{2}{*}{\multicolumn{2}{|c|}{$\begin{array}{l}\text { Approximate } \\
\text { total catch }\end{array}$}} & \multirow[b]{2}{*}{$\begin{array}{l}\text { No. } \\
\text { measured }\end{array}$} & \multicolumn{2}{|c|}{ Length in $\mathrm{mm}$. } \\
\hline & & & & & & Median & Average \\
\hline $\begin{array}{c}1934 \\
\text { March I9 }\end{array}$ & $\begin{array}{l}\text { Iron Rock } \\
\text { Ledges }\end{array}$ & 3 & 200 & & 53 & $7 \cdot 8^{\star}$ & $7 \cdot 3^{\star}$ \\
\hline " 27 & $\begin{array}{l}\text { Iron Rock } \\
\text { Ledges }\end{array}$ & II & 400 & & 83 & $8 \cdot 2$ & $7 \cdot 6$ \\
\hline April 2 & $\begin{array}{l}\text { Iron Rock } \\
\text { Ledges }\end{array}$ & I7 & 32 & & 32 & $\mathrm{II} \cdot 3$ & $10 \cdot 7$ \\
\hline " 9 & Machrie Bay & 24 & 70 & & 69 & $\begin{array}{l}14.8 \\
8.8\end{array}$ & I $2 \cdot 8$ \\
\hline May $\begin{array}{l}30 \\
I\end{array}$ & $\begin{array}{l}\text { Machrie Bay } \\
\text { Keppel }\end{array}$ & $\begin{array}{l}45 \\
46\end{array}$ & $\begin{array}{r}30 \\
300\end{array}$ & & $\begin{array}{r}30 \\
104\end{array}$ & $\begin{array}{l}18 \cdot 8 \\
2 I \cdot 6\end{array}$ & $\begin{array}{l}18 \cdot 3 \\
21 \cdot I\end{array}$ \\
\hline $\begin{array}{r}\text { I935 } \\
\text { April } 3\end{array}$ & $\begin{array}{l}\text { Iron Rock } \\
\text { Ledges }\end{array}$ & I8 & 30 & & 24 & $7 \cdot 2$ & $7 \cdot 3$ \\
\hline $\begin{array}{r}9 \\
\text { 16 }\end{array}$ & Machrie Bay & 24 & $6 \mathrm{I}$ & & 6I & I $4 \cdot 7$ & $14 \cdot 2$ \\
\hline $\begin{array}{ll}\Longrightarrow & 16 \\
, & 22\end{array}$ & $\begin{array}{l}\text { Machrie Bay } \\
\text { Keppel }\end{array}$ & $\begin{array}{l}3 \mathrm{I} \\
37\end{array}$ & $\begin{array}{r}3 \\
22 \mathrm{I}\end{array}$ & & $\begin{array}{r}3 \\
22 \mathrm{I}\end{array}$ & $\overline{20 \cdot 7}$ & $\overline{20 \cdot 2}$ \\
\hline " 23 & $\begin{array}{l}\text { Skipness } \\
\text { Barmore }\end{array}$ & 38 & $\begin{array}{l}25 \mathrm{I} \\
160\end{array}$ & $4 \mathrm{II}$ & 268 & $2 \mathrm{I} \cdot 9$ & $2 I \cdot 2$ \\
\hline , 29 & $\begin{array}{l}\text { Barmore } \\
\text { Otter Spit }\end{array}$ & 44 & $\begin{array}{l}490 \\
495\end{array}$ & 985 & 378 & $26 \cdot 2$ & $25 \cdot 6$ \\
\hline May 2 & $\begin{array}{l}\text { Wemyss Point } \\
\text { Otter Spit }\end{array}$ & $\begin{array}{l}47 \\
52\end{array}$ & $\begin{array}{l}556 \\
824 !\end{array}$ & & $33^{8}$ & $26 \cdot 8$ & $26 \cdot 2$ \\
\hline$\Rightarrow 7$ & $\begin{array}{l}\text { Otter Spit } \\
\text { Gortans Basin } \\
\text { Ardlamont }\end{array}$ & & $\left.\begin{array}{r}824 \\
\text { II } \\
\text { I } 28\end{array}\right\}$ & 963 & $44 \mathrm{I}$ & $27 \cdot 3$ & $26 \cdot 4$ \\
\hline "I4 & $\begin{array}{l}\text { Otter Spit } \\
\text { Ardlamont }\end{array}$ & 59 & $\begin{array}{r}2228 \\
28\end{array}$ & 2256 & $46 \mathrm{I}$ & $32 \cdot 6$ & $3 \mathrm{I} \cdot 6$ \\
\hline$\Rightarrow 2 \mathrm{I}$ & $\begin{array}{l}\text { Otter Spit } \\
\text { Ardlamont }\end{array}$ & 66 & $\left.\begin{array}{r}\mathrm{I} 394 \\
4\end{array}\right\}$ & I398 & 239 & $35^{\circ} 2$ & $34 \cdot 0$ \\
\hline \#27 & Skate I. & 72 & 8 & & 8 & - & $\overline{26 \cdot 4}$ \\
\hline June 5 & $\begin{array}{l}\text { Otter Spit } \\
\text { Otter Spit }\end{array}$ & $\begin{array}{l}75 \\
81\end{array}$ & $\begin{array}{r}3 \text { II } 4 \\
50\end{array}$ & & $\begin{array}{r}265 \\
25\end{array}$ & $\begin{array}{l}36 \cdot 9 \\
37 \cdot 5\end{array}$ & $\begin{array}{l}36 \cdot 4 \\
37 \cdot 9\end{array}$ \\
\hline , 17 & Barmore & 93 & I & & I & & \\
\hline
\end{tabular}

which has too low a value, was taken at the Iron Rock Ledges over the spawning ground, some time after hatching had begun and although a few large specimens were included the catch was composed mainly of late-hatching larvae. A similar explanation probably applies to the catch of April 30 1934, which was the last taken in Kilbrennan Sound that year. It was from Machrie Bay and probably represents larvae hatched later than the main mass which, judging from the 1935 results, had very probably moved farther north by this time. The 
herring from Keppel on May I 1934 were smaller than those taken at the same time in 1935 from Wemyss Point, which suggests either that the herring from

\section{Table II. Length Measurements of Herring}

\begin{tabular}{|c|c|c|c|c|c|c|c|c|c|c|c|c|c|c|c|c|c|}
\hline \multirow[b]{3}{*}{ Mm. } & \multicolumn{6}{|c|}{ I934 } & \multicolumn{11}{|c|}{ I935 } \\
\hline & \multicolumn{2}{|c|}{ March } & \multicolumn{3}{|c|}{ April } & \multirow{2}{*}{$\begin{array}{c}\text { May } \\
\text { I } \\
\text { Keppel }\end{array}$} & \multicolumn{5}{|c|}{ April } & \multicolumn{5}{|c|}{ May } & \multirow{2}{*}{$\begin{array}{r}\text { June } \\
5\end{array}$} \\
\hline & I9 & 27 & 2 & 9 & 30 & & 3 & 9 & $\begin{array}{c}22 \\
\text { Keppel }\end{array}$ & 23 & 29 & $\stackrel{2}{2}$ & 7 & $\mathrm{I} 4$ & $2 \mathrm{I}$ & 30 & \\
\hline 6 & 7 & 9 & - & - & - & - & II & - & - & - & - & - & - & - & - & - & - \\
\hline 7 & 24 & 26 & - & - & - & - & 7 & - & - & - & - & - & - & - & - & - & - \\
\hline 8 & $2 \mathrm{I}$ & 40 & - & - & - & - & 2 & - & - & - & - & - & - & - & - & - & - \\
\hline 9 & I & 8 & 2 & - & - & - & I & - & - & - & - & - & - & - & - & - & - \\
\hline Io & 二 & - & IO & - & - & - & I & 3 & - & - & - & - & - & - & - & - & - \\
\hline II & - & - & I7 & 8 & - & - & I & - & - & - & - & - & - & - & - & - & - \\
\hline I2 & - & - & 2 & I5 & - & $\ldots$ & - & 2 & - & - & - & - & - & - & - & - & - \\
\hline I3 & - & - & I & 30 & - & - & I & Io & - & - & - & - & - & - & - & - & - \\
\hline I4 & - & - & - & $\mathrm{I} 4$ & - & -- & - & 23 & - & - & - & - & - & - & - & - & - \\
\hline $\begin{array}{l}15 \\
15\end{array}$ & - & - & - & $\begin{array}{r}14 \\
2\end{array}$ & I & -- & - & I0 & I & I & - & - & - & - & - & - & - \\
\hline 16 & - & - & - & - & 4 & - & - & IO & I & - & - & - & - & - & - & - & - \\
\hline I7 & - & - & - & - & I & - & - & 3 & 7 & 5 & - & - & - & - & - & - & - \\
\hline I8 & - & - & - & - & $\mathrm{I} 2$ & 7 & - & - & 18 & 5 & - & - & - & - & - & - & - \\
\hline I9 & - & - & - & - & 5 & I6 & - & - & 56 & 37 & - & - & - & - & - & - & - \\
\hline 20 & - & - & - & - & 4 & 13 & - & - & $4 \mathrm{I}$ & $\begin{array}{l}31 \\
45\end{array}$ & - & I & I & - & - & - & - \\
\hline $2 \mathrm{I}$ & - & - & - & - & 3 & 27 & - & - & 49 & 48 & I & I & I 2 & - & - & - & - \\
\hline 22 & - & - & - & - & - & 22 & - & - & 26 & 55 & 9 & 5 & $3 \mathrm{I}$ & - & - & - & - \\
\hline 23 & - & - & - & - & - & I5 & - & - & 20 & $5 \mathrm{I}$ & 29 & I4 & 34 & - & - & - & - \\
\hline 24 & - & - & - & - & - & 2 & - & - & 2 & 20 & 52 & 27 & $\begin{array}{l}34 \\
22\end{array}$ & I & - & - & - \\
\hline 25 & - & - & - & - & - & 2 & - & - & - & $\mathrm{I}$ & 78 & 44 & 37 & 3 & - & - & - \\
\hline 26 & - & - & - & - & - & - & - & - & - & - & IIO & 92 & 66 & I0 & - & - & - \\
\hline 27 & - & - & - & - & - & - & - & - & - & - & 69 & 90 & 68 & 38 & - & - & - \\
\hline 28 & - & - & - & - & - & - & - & - & - & - & $2 \mathrm{I}$ & 58 & 77 & 27 & 5 & - & - \\
\hline 29 & - & - & - & - & - & - & - & - & - & - & 8 & 6 & 49 & 29 & 9 & - & - \\
\hline 30 & - & - & - & - & - & - & - & - & - & - & I & - & $\begin{array}{l}49 \\
26\end{array}$ & 40 & 12 & I & - \\
\hline 31 & - & - & - & - & - & - & - & - & - & - & - & - & I2 & 52 & I9 & - & I \\
\hline 32 & - & - & - & - & - & - & - & - & - & - & - & - & 6 & 49 & 23 & I & I \\
\hline 33 & - & - & - & - & - & - & - & -- & - & - & - & - & - & $8 \mathrm{I}$ & 25 & 9 & 2 \\
\hline 34 & - & - & - & - & - & - & - & - & - & - & - & - & - & 60 & 20 & $3 I$ & 3 \\
\hline 35 & - & - & - & - & - & - & - & - & - & - & - & - & - & 52 & 30 & 45 & 4 \\
\hline 36 & - & - & - & - & - & - & - & - & - & - & - & - & - & I6 & 34 & 54 & - \\
\hline 37 & - & - & - & - & - & - & - & - & - & - & - & - & - & 3 & 28 & 50 & \\
\hline 38 & - & - & - & - & - & - & - & - & - & - & - & - & - & - & & 39 & I \\
\hline 39 & - & - & - & - & - & - & - & - & - & - & - & - & - & - & 8 & 23 & I \\
\hline 40 & - & - & - & - & - & - & - & - & - & - & - & - & - & - & 3 & 6 & I \\
\hline $4 \mathrm{I}$ & - & - & - & - & - & - & - & - & - & - & - & - & - & - & & 5 & I \\
\hline 42 & - & - & - & - & - & - & - & - & - & - & - & - & - & - & - & I & 2 \\
\hline 43 & - & - & - & - & - & - & - & - & - & - & - & - & - & - & - & - & - \\
\hline 44 & - & - & - & - & - & - & - & - & - & - & - & - & - & - & - & - & I \\
\hline & - & - & - & - & - & - & - & - & - & - & - & - & - & - & - & - & - \\
\hline $\begin{array}{l}43 \\
46\end{array}$ & - & - & - & - & - & - & - & - & - & - & - & - & - & - & - & - & I \\
\hline 47 & - & - & - & - & - & - & - & - & - & - & - & - & - & - & - & - & - \\
\hline 48 & - & - & - & - & - & - & - & - & - & - & - & - & - & - & - & - & I \\
\hline 49 & - & - & - & - & - & - & - & - & - & - & - & - & - & - & - & - & I \\
\hline Total & 53 & 83 & 32 & 69 & 30 & IO4 & 24 & 6I & $22 \mathrm{I}$ & 268 & 378 & 338 & $44 \mathrm{I}$ & $46 \mathrm{I}$ & 239 & 265 & 25 \\
\hline
\end{tabular}

Ballantrae Banks in I934 were smaller than those of 1935 , or more probably, that we were again dealing with late-hatching larvae, the main shoal being farther north. The second alternative is supported by the catch from Keppel on April 22 I935, which although of similar size to that of May I 1934, was taken as 
much as nine days earlier. Moreover, both the 1935 catches of presumed Ballantrae origin fit in well with the main curve. The last haul (June 5 I935) was a poor sample ( $25 \mathrm{fish}$ ) and was taken at the time of metamorphosis when most of the herring had disappeared from our catches leaving only fish which would be late hatchers or poor growers and therefore smaller. The effect of the larger fish metamorphosing and disappearing would probably affect the previous haul (May 30) to a certain extent.

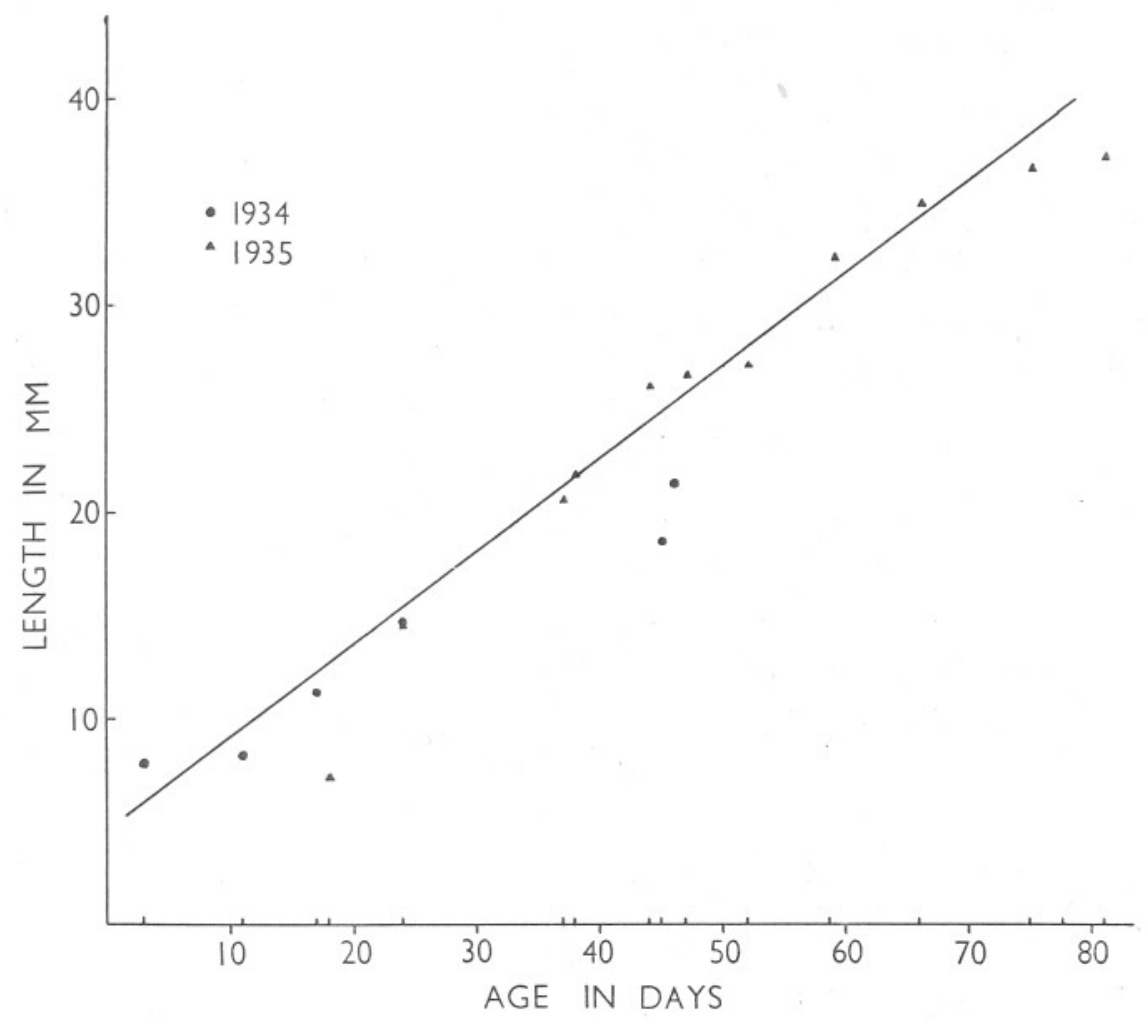

Fig. 2. Relation of length to age in pre-metamorphosis herring.

In the samples the range in size gradually increased as the larvae grew, owing in part at least to the unequal growth of the individuals.

A comparison of the rate of growth of the Clyde herring larvae with those from elsewhere shows on the whole a good agreement. Obviously the comparison can be made only with spring spawned herring because autumn spawned fish are exposed to different conditions of temperature and feeding. Meyer (1878), dealing with the spring Baltic herring spawned in March in Kiel Bay, concluded that the larvae reached a size of $\mathrm{I} 7-\mathrm{I} 8 \mathrm{~mm}$. at I month, 34-36 mm. at 2 months, and 45-50 mm. at 3 months. The results of Ekstrom, 
Nilsson, and Hoek, summarized by Fulton (1906), and those of Runnstrøm (1934) also agree fairly well although the growth in their herring seems to slow off in May and June, so that metamorphosis does not take place until July or August. The only divergent results are those of Masterman (I896) on herring caught in St Andrews Bay. Although his larvae, hatched in midMarch, were $15 \mathrm{~mm}$. at the end of I month, a figure which agrees fairly well with ours, the growth after this was only $4-5 \mathrm{~mm}$. per month, so that after 7 months, the herring were only $44 \mathrm{~mm}$. The results of the collections of larvae made by the Fishery Board for Scotland from I904-32 (Clark, I933) show, for the spring hatched larvae, a slow growth in the early months and a rapid growth in the later months. This is not borne out by our results, which show a uniform monthly increment, although the size attained in June is much the same in both cases.

The stage of development reached by the Clyde herring at any particular length agrees well with Lebour's (I92I $a$ ) description. Thus the larvae lose the yolk-sac and begin to develop the dorsal fin at about ro mm., the end of the notochord turns up at about $17 \mathrm{~mm}$. and pelvic fins appear at about $22 \mathrm{~mm}$. When the Clyde larvae were about $30-35 \mathrm{~mm}$. the caecal part of the stomach began to form and the air bladder became prominent. The smallest metamorphosing herring measured $42 \mathrm{~mm}$.

\section{Food and its Relation to the Plankton}

\section{Food}

In every catch of herring larvae, the guts of those feeding were examined and their contents noted. The proportion feeding was seldom large and was sometimes as low as I \%. Hardy (1924) has suggested that on capture the young herring ejects the food in the gut, and this is possibly the cause of the small proportion containing food. Quite often there were swellings in the empty gut as if it had recently contained food.

The food was almost invariably in the intestine, unless the fish had begun metamorphosis, and although crushed and often broken up the greater part was usually recognizable. Table III shows the food from all the guts examined in each day's catch, expressed as the numbers of organisms in roo feeding herring. The identifications may not be invariably correct, especially where it depends on size, but most of the copepodites were easily recognizable.

It is well known (Lebour, I92I $b$, I924; Hardy, I924; Ogilvie, I927) that herring larvae feed first on diatoms and unicellular organisms. Although recognizable diatom skeletons were found in only a few of the present samples, there was in the guts of most of the yolk-sac stages which contained anything a greenish mush, possibly the remains of diatoms or flagellates. This mush was only once seen in a herring large enough to have developed a dorsal fin, but unbroken diatom skeletons were occasionally seen in quite large specimens (40 mm.). 
Copepods were the main food after the yolk-sac stage, first as nauplii, but very soon as copepodites and the adults of the smaller forms. Up to the end of April 1935 Pseudocalanus, Microcalanus and Oithona were the most important as food. In May Centropages, Temora and Acartia were eaten freely as well.

In the catches from any one station one organism frequently predominated. Thus on May 7 I935 more Temora and Cladocera were eaten than any other organism, whereas on May I4 1935 Centropages and Cladocera predominated. On May 2I Centropages again predominated but Temora was nearly as abundant and the numbers of Pseudocalanus and Acartia had also increased. There was a great change in the following week when the majority of the herring contained little but Calanus eggs. The eggs of Pseudocalanus and Calanus differ but little in size and in the gut of the herring they may be confused with one another or even with other crustacean eggs such as those of Cladocera; they have therefore been lumped together in Table III. At this time, however, the eggs of the second brood of Calanus were appearing and there is no doubt that the great majority, averaging 700 in each feeding herring, were those of Calanus. The greatest number found in one gut was 1652 . In the samples from the following week eggs were much less abundant and nauplii much more so; the single specimen obtained on June 17 contained 33 Calanus copepodites.

Cestode larvae and trematodes were frequently found as parasites in the gut. The latter were more common and the incidence appeared to increase as the herring grew, as many as $29-30 \%$ being parasitized in the large catches of May $2 \mathrm{I}$ and 30 . Cestode larvae were less numerous and they too were more frequent in the older herring.

\section{Plankton}

On each occasion that herring larvae were caught in any reasonable quantity (except when taken from Keppel Pier) a vertical haul was taken with the $\frac{1}{2} \mathrm{~m}$. fine silk standard net and all the zooplankton organisms picked out and counted, usually in the whole sample, for comparison with the analyses made of the gut contents of the herring. At the beginning of 1934 only copepods, copepod nauplii, and cirripede larvae were counted, but later and during 1935 the analysis was extended to include all zooplankton organisms. The results are shown in Table IV.

Since the chief purpose of taking these hauls was for comparison with the food of the young herring it was essential that they should be taken at the same time and place as that in which the young herring were found. This resulted in a considerable loss in uniformity of the hauls, since some were taken close inshore and others in deep water, and in different parts of the area; thus apart from the changes in depth, and therefore length of haul and quantity of water filtered, there would naturally be a change in the type of plankton caught. The hauls are therefore not strictly comparable one with another and are of little value unless taken in conjunction with the analyses of the herring food. 
TABle III. Food Per ioO FeEding Herring

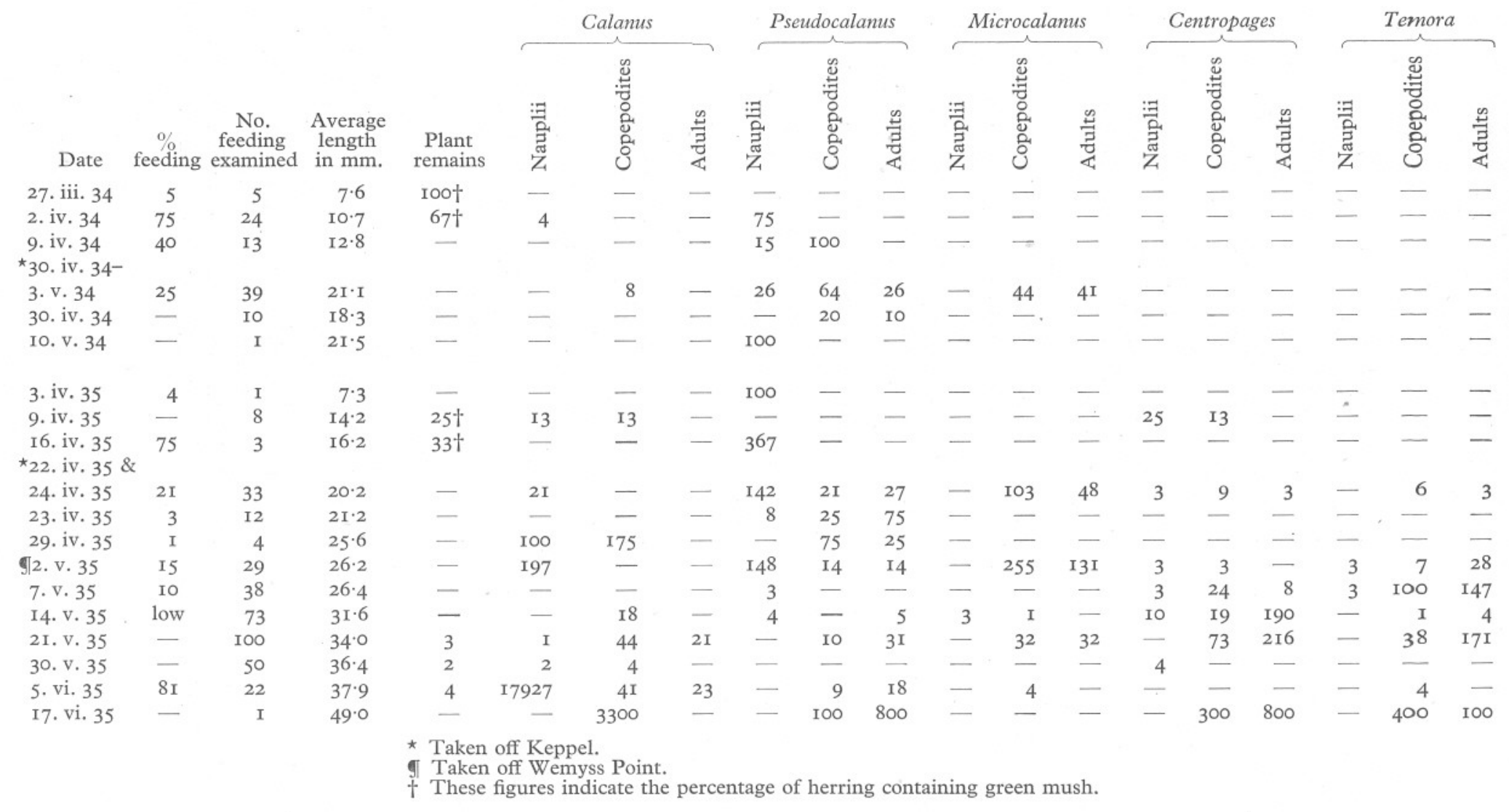


TABLE III (continued)

\begin{tabular}{|c|c|c|c|c|c|c|c|c|c|c|c|c|c|c|c|c|c|c|}
\hline & & & & \multicolumn{3}{|c|}{ Acartia } & \multicolumn{3}{|c|}{ Oithona } & \multirow[b]{2}{*}{ 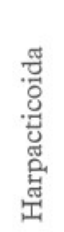 } & \multirow[b]{2}{*}{ 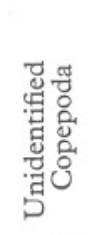 } & \multirow[b]{2}{*}{ 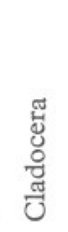 } & \multirow[b]{2}{*}{ 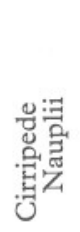 } & \multirow[b]{2}{*}{ 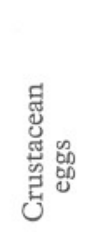 } & \multirow[b]{2}{*}{ 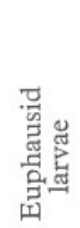 } & \multirow[b]{2}{*}{$\begin{array}{l}\text { జँ } \\
\text { N }\end{array}$} & \multirow[b]{2}{*}{ 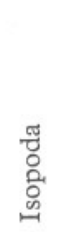 } & \multirow[b]{2}{*}{ 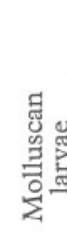 } \\
\hline Date & $\begin{array}{c}\% \\
\text { feeding }\end{array}$ & $\begin{array}{c}\text { No. } \\
\text { feeding } \\
\text { examined }\end{array}$ & $\begin{array}{c}\text { Average } \\
\text { length } \\
\text { in } \mathrm{mm} .\end{array}$ & $\begin{array}{l}\text { : } \\
\text { 总 } \\
\text { Z }\end{array}$ & 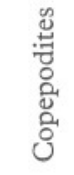 & 营 & 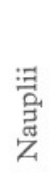 & 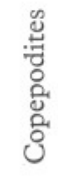 & 缹 & & & & & & & & & \\
\hline 27. iii. 34 & 5 & 5 & $7 \cdot 6$ & - & - & - & - & - & - & - & 40 & - & - & - & - & - & - & - \\
\hline 2. iv. 34 & 75 & 24 & $10 \cdot 7$ & - & - & - & - & - & - & - & $3^{8}$ & - & - & - & - & - & - & - \\
\hline $\begin{array}{l}\text { 9. iv. } 34 \\
\star 30 . \text { iv. } 34-\end{array}$ & 40 & 13 & I $2 \cdot 8$ & - & - & - & - & - & - & - & $3 \mathrm{I}$ & - & - & - & - & - & - & - \\
\hline 3. v. 34 & 25 & 39 & $2 I \cdot I$ & 5 & - & Iо & - & 23 & 5 & 3 & IIO & 3 & - & I67 & - & - & - & 3 \\
\hline 3o. iv. 34 & - & IO & $18 \cdot 3$ & - & I0 & - & - & - & Io & IO & 50 & - & - & 2680 & - & - & - & Io \\
\hline Io. v. 34 & - & I & $21 \cdot 5$ & - & - & - & - & - & - & - & - & - & - & - & - & - & - & - \\
\hline 3. iv. 35 & 4 & I & $7 \cdot 3$ & - & - & - & - & - & - & - & - & - & - & - & - & - & - & - \\
\hline 9. iv. 35 & - & 8 & $14 \cdot 2$ & - & - & - & - & - & - & I3 & 38 & - & - & - & - & - & -- & - \\
\hline I6. iv. 35 & 75 & 3 & $16 \cdot 2$ & - & - & - & - & - & - & - & - & - & - & - & - & - & - & - \\
\hline$\star_{22}$. iv. $35 \&$ & & & & & & & & & & & & & & & & & & \\
\hline 24. iv. 35 & $2 \mathrm{I}$ & 33 & $20 \cdot 2$ & - & - & 3 & - & 67 & 48 & - & 42 & - & 3 & 24 & 3 & - & - & - \\
\hline 23. iv. 35 & 3 & 12 & $2 \mathrm{I} \cdot 2$ & - & - & - & - & 8 & - & - & - & - & - & 300 & - & - & - & \\
\hline 29. iv. 35 & I & 4 & $25 \cdot 6$ & - & - & - & - & - & - & - & 50 & - & - & - & - & - & - & \\
\hline 9/2. v. 35 & I5 & 29 & $26 \cdot 2$ & - & - & 3 & - & 28 & IO & - & 45 & - & Io & 1107 & - & - & - & 396 \\
\hline 7. v. 35 & IO & 38 & $26 \cdot 4$ & - & 8 & 13 & - & - & - & - & 5 & 252 & - & - & - & - & - & 3 \\
\hline I4. v. 35 & low & 73 & $3 \mathrm{r} \cdot 6$ & - & 3 & 34 & - & I & - & I & 4 & 200 & - & 95 & - & - & - & 27 \\
\hline 21. V. 35 & - & 100 & $34 \cdot 0$ & - & 5 & $7 \mathrm{I}$ & - & - & - & I & 8 & 27 & 5 & 690 & - & 2 & I & 36 \\
\hline 3o. v. 35 & - & 50 & $36 \cdot 4$ & - & 2 & 8 & - & - & - & 38 & 6 & 78 & - & 70432 & - & - & - & 36 \\
\hline 5. vi. 35 & $8 \mathrm{I}$ & 22 & 37.9 & - & I8 & 4 & - & 4 & - & 4 & 104 & 59 & 18 & 37905 & - & - & - & 36 \\
\hline I7. vi. 35 & - & I & $49 \cdot 0$ & - & 100 & 300 & - & - & - & - & 9400 & - & - & 100 & - & - & - & \\
\hline
\end{tabular}


Table IV. Zooplankton in Vertical Hauls with $\frac{1}{2}$ M. Fine Silk Net

Calanus

copepodites

Pseudocalanus and

Paracalanus

Microcalanus

Centropages

Temora

Acartia

Oithon

Harpacticoida

Calanus eggs

Calanus naupli

Other nauplii

Euphausidae

Decapoda

Appendicularia

Polychaete larvae

Echinoderm larvae

Cladocera

Molluscan larvae

Microniscus

Fish eggs

Chaetognatha

Cirripede nauplii

Other calanoids

Rotifera

Medusae

Other larvae

Cyphonautes

Amphipoda

Nematoda

\begin{tabular}{|c|c|c|c|c|c|}
\hline \multicolumn{6}{|c|}{$\underbrace{1934}$} \\
\hline \multicolumn{3}{|c|}{ March } & \multicolumn{3}{|c|}{ April } \\
\hline I3 & I9 & 27 & 2 & 9 & 30 \\
\hline 25 & 5 & 7 & 20 & 560 & $2 \mathrm{I}$ \\
\hline I6I & I4 & I 76 & 3150 & $8 \mathrm{I} 70$ & 22 \\
\hline $27 \mathrm{I}$ & 37 & I7 & - & 750 & - \\
\hline & I & 33 & 70 & I IO & 95 \\
\hline 13 & 2 & 24 & 70 & 90 & 2 \\
\hline 12 & 4 & 68 & 120 & 80 & 183 \\
\hline 214 & 33 & 39 & I30 & 1260 & - \\
\hline 12 & 4 & I & 20 & 40 & $\begin{array}{r}35 \\
1520\end{array}$ \\
\hline$\overline{637}$ & $\overline{18} 86$ & $\overline{\mathrm{I} 856}$ & 9010 & $9100^{5}$ & $\begin{array}{r}1520 \\
303\end{array}$ \\
\hline \multirow[t]{9}{*}{32} & 4 & 2 & - & 60 & 2 \\
\hline & & & 30 & $\begin{array}{r}120 \\
\text { IO }\end{array}$ & 3 \\
\hline & & & IIO & $\begin{array}{r}\text { I0 } \\
370\end{array}$ & 3 \\
\hline & & & I 40 & $\begin{array}{l}370 \\
500\end{array}$ & 二 \\
\hline & & & IO & IO & Z \\
\hline & & & 30 & IOO & - \\
\hline & & & - & 60 & 4 \\
\hline & & & $\overline{20}_{20}$ & 二 & 2 \\
\hline & & & 60 & - & - \\
\hline \multirow{6}{*}{ I23 } & $\begin{array}{l}44 \\
18\end{array}$ & $\begin{array}{r}0 \\
50\end{array}$ & - & 20 & ${ }^{1}$ \\
\hline & & & 780 & - & - \\
\hline & & & IO & I0 & - \\
\hline & & & 100 & 190 & $\bar{I}_{\mathrm{I}}$ \\
\hline & & & - & - & - \\
\hline & & & 一 & 一 & - \\
\hline
\end{tabular}

I935

\begin{tabular}{|c|c|c|c|c|c|c|c|c|c|}
\hline \multicolumn{5}{|c|}{ April } & \multicolumn{5}{|c|}{ May } \\
\hline 3 & 9 & I6 & 23 & 29 & 2 & 7 & I4 & $2 I$ & 30 \\
\hline 96 & 316 & 444 & I 744 & 368 & 183 & 339 & 674 & 399 & 478 \\
\hline 28 & 285 & I89 & 630 & 57 & 88 & I 74 & 205 & $22 \mathrm{I}$ & I 68 \\
\hline I4 & - & 92 & 1600 & 1080 & $63 \mathrm{I}$ & 385 & 721 & $\mathrm{I} 87 \mathrm{I}$ & IOI2 \\
\hline I0 & 382 & 96 & 52 & 39 & 2 & $2 \mathrm{I}$ & 64 & 22 & 48 \\
\hline 9 & 66 & 37 & 28 & 6 & I5 & 374 & 4 & I I & 4 \\
\hline 17 & I 32 & 77 & 22 & II 7 & 8 & 345 & 476 & I58 & 292 \\
\hline 130 & 48 & I47 & 206 & 27 & 67 & 26 & 55 & 28 & 16 \\
\hline & 5 & 28 & 15 & 53 & 5 & 3 & 7 & I3 & 6 \\
\hline 25 & 12 & 4 & 20 & 525 & 1344 & 848 & 592 & 1424 & 12340 \\
\hline 367 & 224 & 540 & 400 & 235 & 964 & 256 & 400 & 392 & 8570 \\
\hline 350 & $1440^{\circ}$ & 492 & 2920 & 1800 & 300 & 536 & 388 & 520 & 1510 \\
\hline 43 & 35 & 14 & 20 & 7 & I3 & $\mathrm{I} 2$ & I & - & 16 \\
\hline I & & I & - & . & I & I & - & I & I \\
\hline 54 & I6 & - & 4 & - & 2 & - & 2 & I & 7 \\
\hline 89 & 48 & 56 & 28 & 20 & 5 & 27 & 9 & I9 & I4 \\
\hline 27 & I3 & 6 & I5 & - & 5 & - & & 8 & 300 \\
\hline 5 & 54 & 89 & & 79 & & II 2 & 22 & 8 & I4 \\
\hline 23 & 50 & 138 & 1600 & 450 & 852 & 69 & I & I & 9 \\
\hline- & & 2 & 3 & 6 & 4 & 4 & 4 & 6 & 3 \\
\hline IO & 9 & 9 & 12 & - & I0 & 3 & 3 & - & 12 \\
\hline 4 & 7 & 2 & I & - & - & & & - & I \\
\hline I9 & 79 & 29 & 2 & I & 13 & 3 & 3 & - & \\
\hline I & 2 & I & - & 2 & I & I & 2 & - & I \\
\hline & - & & - & 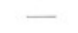 & - & - & - & - & - \\
\hline- & I2 & 2 & - & - & - & - & - & - & - \\
\hline- & - & - & - & - & - & - & - & - & - \\
\hline- & 2 & 7 & 7 & 3 & I & - & - & - & - \\
\hline - & 一 & 7 & I & 一 & - & - & - & - & - \\
\hline - & - & I & - & - & - & - & - & - & - \\
\hline
\end{tabular}

$\begin{array}{lllllll}\text { Total } & \text { I508 } & 392 & 2279 & \text { I3880 } & \text { 2I6I5 } & 2197\end{array}$ 
The more important copepods occurred in every haul, with the exception of Microcalanus which was absent from three hauls. It may be noted that these hauls were from shallow water fairly close inshore; while not invariably absent from hauls of shallow depth Microcalanus always occurred in hauls taken in deeper water.

The total number of organisms was usually less than 5000 but rose on one or two occasions considerably above this figure, the increase being due to the presence of Calanus eggs in large quantities during the breeding periods.

Apart from the Copepoda individual species showed occasional sudden increases which lasted for a longer or shorter time. Notable among these outbursts was that of the molluscan larvae which rose from I38 on April I6 I935 to 1600 in the following week, remained fairly high $(450,852)$ for the two succeeding weeks, falling below Ioo a week later. The first two of these hauls were taken in the Kilbrennan Sound, the third and fifth at the Otter Spit; the fourth was taken at Wemyss Point and is therefore possibly not comparable.

\section{Relation between Food and Plankton}

The comparison of the plankton analyses with the food taken presents some difficulties. Firstly, since vertical hauls only were taken, they were not representative of the plankton at the particular depth at which the herring were captured. The herring were usually caught fairly near the surface and some copepods, for instance Microcalanus, are found mainly in deep water. On the other hand the herring were not necessarily feeding at the depth where they were caught, for the fact that the food was usually in the intestine indicates that digestion had been going on for some time. Secondly, the size of the herring must be taken into,consideration, for while they are small they tend to take only the smaller organisms. In Table V therefore, in which the food and the plankton are compared, the food organisms have been arranged in order of their abundance in the herring guts and compared with the common food organisms arranged in order of their abundance in the vertical hauls.

At a length of $10.7 \mathrm{~mm}$. (April 2 I934) the herring were taking only nauplii from a choice of nauplii and Pseudocalanus. A week later, at a size of I2.8 mm., Pseudocalanus copepodites were included in their diet, and with a further increase of $2 \mathrm{~mm}$. in length (April 9 1935) Calanus and Centropages were being eaten.

In a few instances (e.g. April 9 1935, May 2 I935) the correlation between gut contents and townettings is very good, and the organisms most frequent in the gut were those most abundant in the vertical haul, but as a rule only a general relationship can be made out.

Although Calanus was usually one of the more numerous copepods in the townettings it was not eaten in numbers until the middle of May, when the herring had reached the length of about $30 \mathrm{~mm}$. In 1935 Oithona was eaten more often in April and the beginning of May than later, corresponding to its 


\section{Table V. Comparison of Herring Food and Plankton}

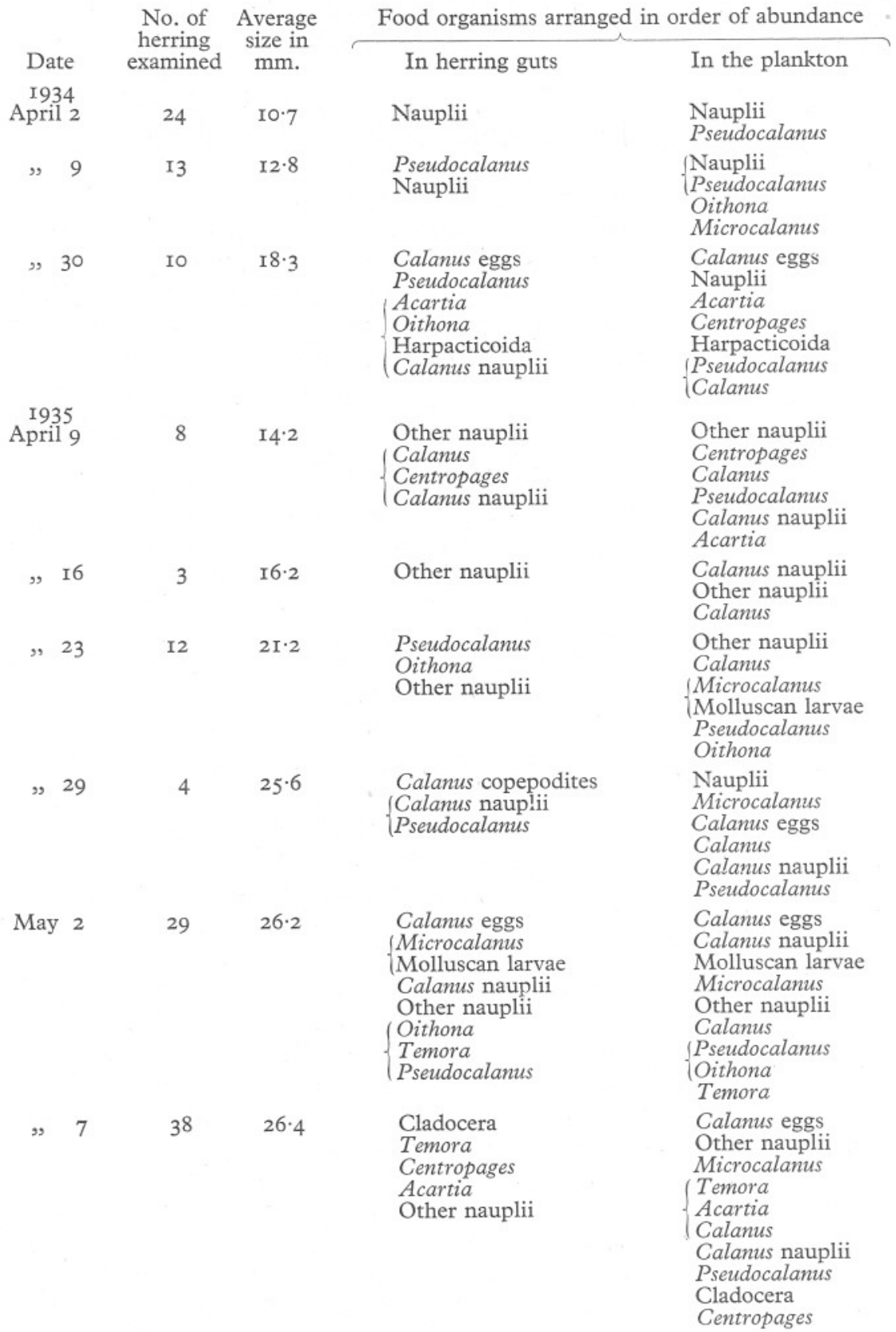




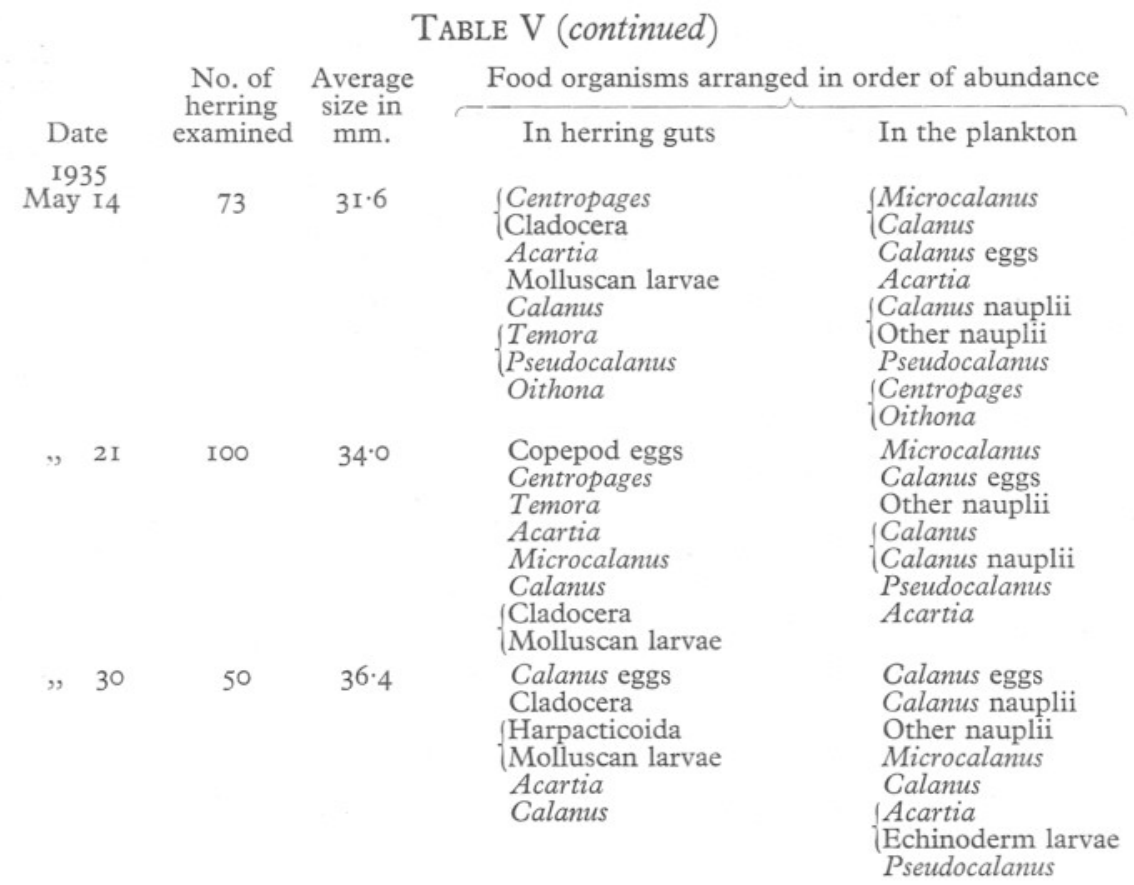

occurrence in the townettings, and Acartia was more abundant in both guts and townettings from May 7 onwards. Centropages and Temora were also eaten more frequently after May 7 , but since there was no corresponding increase in their numbers in the townettings this may have been because they were too large to be eaten freely by the younger larvae. The most striking correspondence between gut content and plankton counts is perhaps that already mentioned for May 30 when the second brood of Calanus eggs appeared.

The conclusions to be drawn are firstly, that the food taken is dependent on the size of the herring, particularly in the first month; secondly, that having attained the requisite size the larvae may take whatever happens to be present; and thirdly, that although en masse they appear to exercise no selection, occasionally one herring may be found with one organism predominant in its gut.

\section{Comparison with Observations elsewhere}

The present work on the food of the young herring confirms results already obtained in the North Sea and English Channel. Lebour (I92I b, I924, I933) deals chiefly with the younger stages. She too found that a large proportion of the youngest stages contain no recognizable food, but she also found that larval molluscs, particularly gastropods, were very important for the young herring up to Io or $12 \mathrm{~mm}$. In the Clyde these did not occur in herring guts at this stage, possibly because they were not numerous in the plankton until the end of April. 
The herring examined by Ogilvie (1927) ranged in size from 27.5 to $45.5 \mathrm{~mm}$. and were taken in three hauls, one in April and two in June off the east coast of Scotland. In all three hauls over $90 \%$ of the herring were feeding, a percentage very much greater than is usually found in the Clyde. The food consisted almost entirely of copepods, of which Pseudocalanus elongatus was most numerous in one catch, Oithona similis in the second, and Eurytemora hirundinoides in the third. Copepod ova are also mentioned as "fairly abundant" on several occasions. The amount of food per fish is much greater than that in the Clyde fish.

Hardy's (1924) observations cover all stages of the young herring up to and beyond metamorphosis. Although a larger percentage of his herring were feeding $(47.8 \%$ of the $12.5-42.0 \mathrm{~mm}$. stages) the amount of food taken per fish seems to be much the same as or rather less than that in the Clyde. Pseudocalanus was by far the most important copepod. Temora and Microcalanus occurred in small numbers, but Calanus, Centropages and Oithona were not taken at all at this stage. Hardy suggests that Calanus and Temora, which were present in the plankton at the time, were not eaten because of their size. In the Clyde, however, an adult Temora was eaten by a herring of $22.5 \mathrm{~mm}$. and many by those of $25-30 \mathrm{~mm}$. Calanus also was eaten by quite small herring; a Stage I copepodite was found in a herring of $16.5 \mathrm{~mm}$., six Stage I in a herring of $23 \mathrm{~mm}$., Stages IV and V were found in herring of $33 \mathrm{~mm}$., and adults in herring from $35 \mathrm{~mm}$. upwards.

Ogilvie mentions the great increase in the amount of food taken by herring of and over $40 \mathrm{~mm}$. This is confirmed by the examination of the single Clyde herring of $49 \mathrm{~mm}$. which contained I 56 copepodites. Apart from this specimen the largest number of copepodites found in any one gut was 69 in a $35 \mathrm{~mm}$. fish (I Calanus, 8 Pseudocalanus, 43 Microcalanus, 4 Temora and I3 Acartia), as well as 7 cladocera, I lamellibranch larva and I8 copepod eggs.

\section{WeIGHT AND Composition}

Samples of the herring captured were weighed. Since it proved difficult to keep a sufficient number alive they were usually fixed in neutral formalin immediately after capture and weighed within I or at most 2 days. The loss in dry weight due to fixation is small in that time. It is very probable that measurements of the wet weight on fixed material would be unreliable, so dry weight alone was measured. The herring were rinsed with distilled water and dried to constant weight at $105-110^{\circ} \mathrm{C}$. During the first few weeks after hatching, the range in size in individual catches was small and a mixed sample was measured and weighed. As the herring became larger, the range in size in individual samples increased; for this reason not only was a mixed sample of the catch taken for weight estimation (Series I, Figs. 3 and 4) but a series of herring samples of different millimetre size groups was also weighed (Series 2-5, Figs. 3 and 4 ). 
The results of the weighings are shown in Table VI and Fig. 3. As might be expected the curve showing the weight-length relationship is exponential in

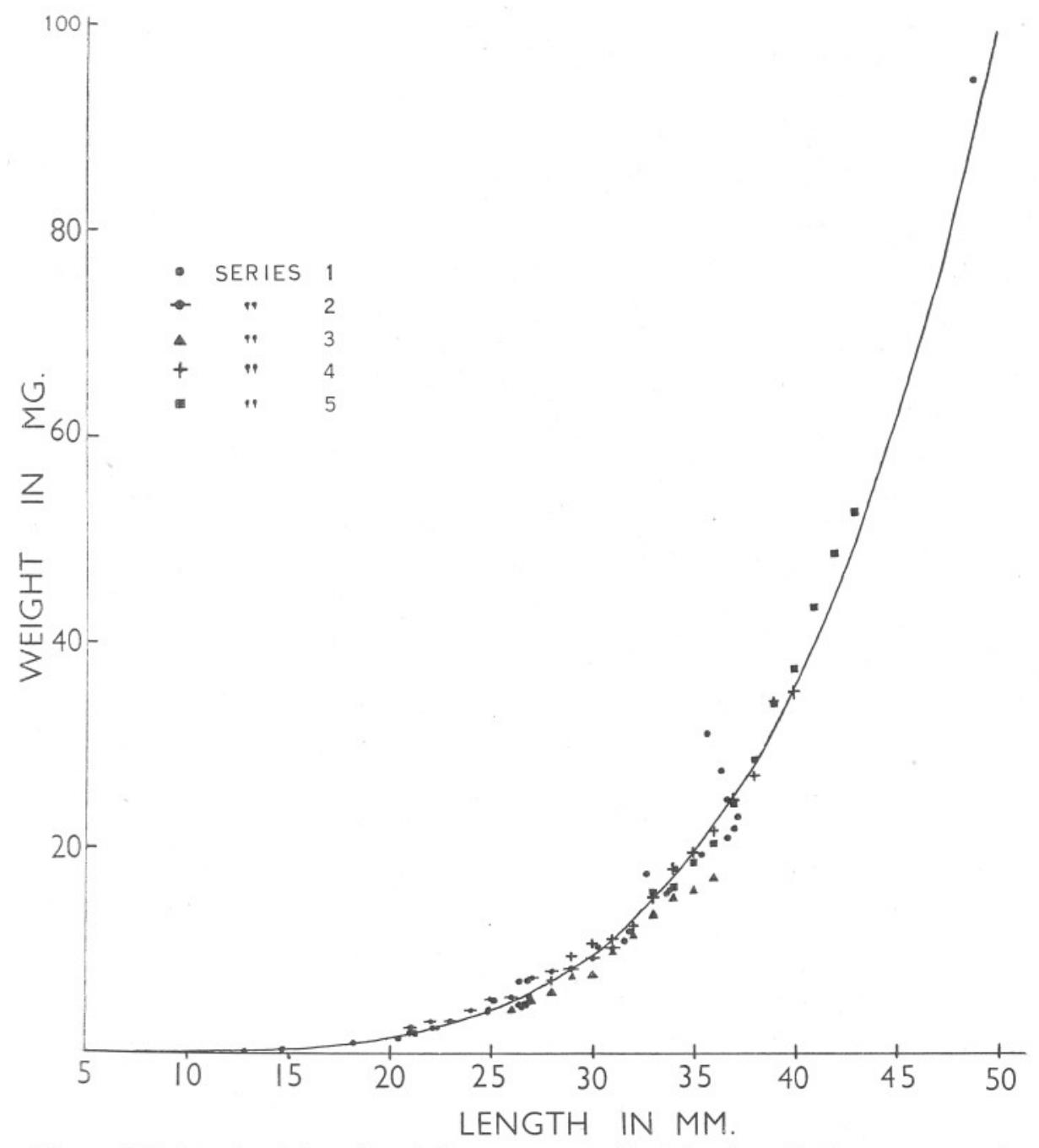

Fig. 3. Relation of weight to length in pre-metamorphosis herring. Series I, average of a sample of each catch; Series 2, May 7 1935; Series 3, May I4 I935; Series 4, May 21 I935; Series 5, May 301935.

form. The curve drawn is that for $W=0.0000020 L^{4 \cdot 52}$, the theoretical curve derived from the data. Above $40 \mathrm{~mm}$., when the fish are approaching metamorphosis, they are slightly heavier than would be expected. The point at $49 \mathrm{~mm}$. represents one fish which had completely metamorphosed. 


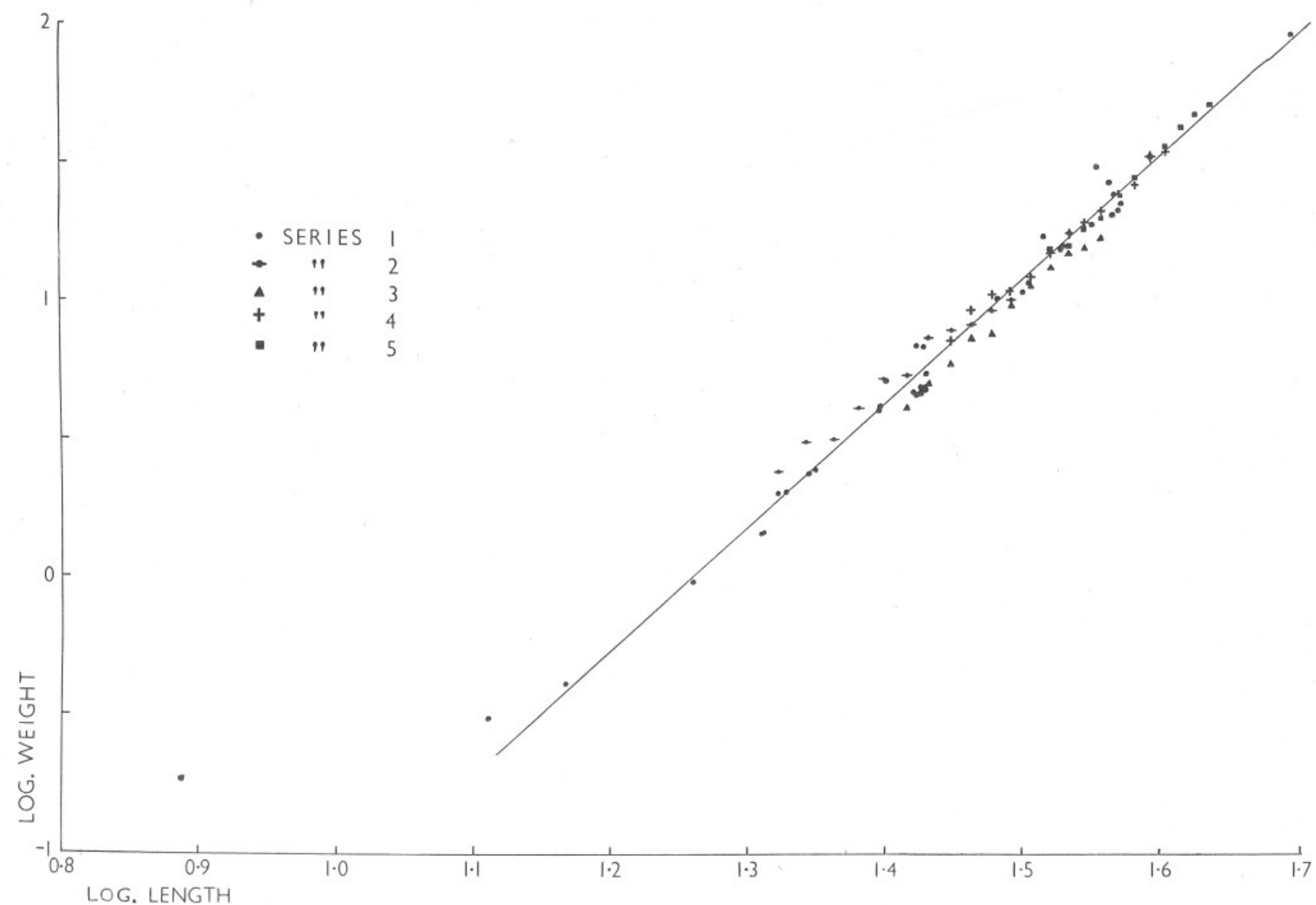

Fig. 4. Relation of logarithm of weight to logarithm of length in pre-metamorphosis herring. Series $\mathrm{I}-5$ as in Fig. 3. 
By plotting the logarithms of the length against the logarithms of the weight it is shown (Fig. 4) that with one exception the points lie on or near a straight line. Excluding this one point the equation of the theoretical straight line was found by the method of least squares to be $Y=4.52 X-5 \cdot 70$, i.e.

$$
W=0.0000020 L^{4.52} \text {, }
$$

where $W$ represents the weight and $L$ the length. The relation between length and weight usually taken for fish is $W=F L^{3}$, where $F$ is a constant. Since in the present instance the dry weight only was measured, a direct comparison of pre-metamorphosis herring with other fish cannot be made, but by comparing our figures with those given by Fulton (1904) and thus taking the water content as $85 \%$, we find that the weight is proportional more nearly to the fourth power of the length than to the third.

The first point does not fit the curve (Fig. 4) and has been omitted from the calculations because herring at this size still have a prominent yolk-sac; the weight measurement was thus not truly comparable with those above $10 \mathrm{~mm}$. when the yolk-sac has disappeared.

The fat content of the herring was estimated in samples taken on and after April 23 1935. For this purpose a suitable number of herring was taken while still alive, rinsed in distilled water and transferred to a small quantity of alcohol on board. On returning to the laboratory they were dried and weighed and the fat estimated by Stoddard \& Drury's (I929) method.

The results are shown in Table VI and are expressed as percentage of fat in the dried herring. The fat content of pre-metamorphosis fish is much lower than that of adult herring, but there is a rise in fat content as the fish approach metamorphosis. At about $25 \mathrm{~mm}$. the young herring had a fat content of $3.5 \%$; a sample a week later had $5 \%$ but in the two following weeks it was only 4.3 and $4 \cdot 7 \%$. The small sample of May 27 had $5.7 \%$ fat while the large sample of May 30 had $8.5 \%$. This figure was verified using the Soxhlet ether extraction method. The sample of June 5 which was small in numbers and showed a decrease in size had a lower fat content $(4.9 \%)$. It is apparent that while increase in size in pre-metamorphosis herring is accompanied in general by an increase in fat content, the rate of increase is not regular. This may be due to inaccurate sampling of the catch or to variations in the condition of the herring themselves.

\section{EXPERIMENTAL WORK}

An attempt was made to rear larval herring in the aquarium, from spawn obtained either naturally or artificially, with the object of making experiments on their metabolism. As other observers have found, it is almost impossible to keep the larvae alive after they have lost the yolk-sac. After this stage there is no increase in length and an actual loss in weight. Experiments with newly hatched larvae, however, are probably reliable. 
Table VI. Weight and Fat Content of Herring

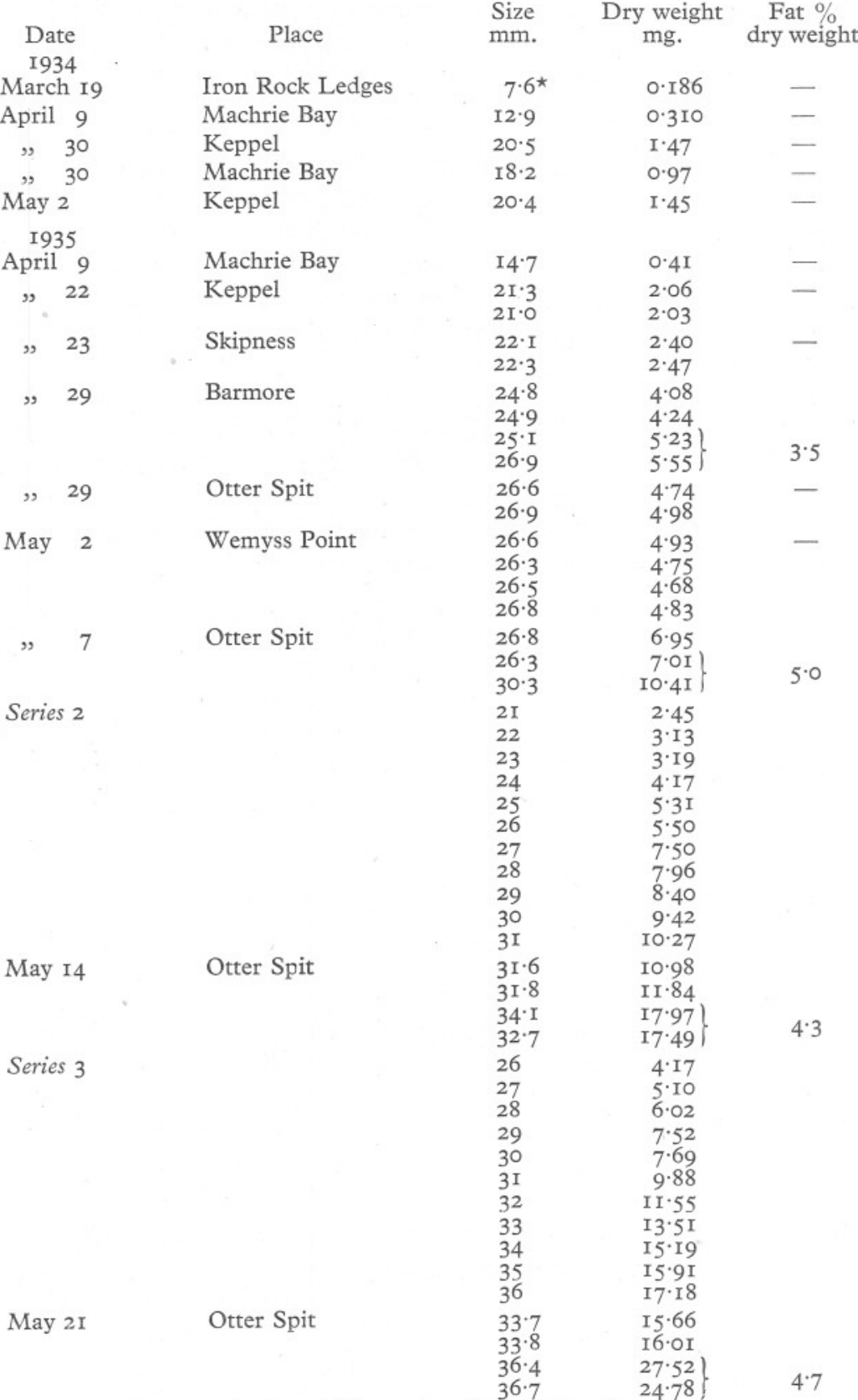

* In the first sample the tail fin was not included in the measurement. 
TABLE-VI (continued)

\begin{tabular}{|c|c|c|c|c|}
\hline \multirow{2}{*}{$\begin{array}{l}\text { Date } \\
\text { I935 }\end{array}$} & Place & $\begin{array}{l}\text { Size } \\
\mathrm{mm} \text {. }\end{array}$ & $\begin{array}{l}\text { Dry weight } \\
\text { mg. }\end{array}$ & $\begin{array}{c}\text { Fat \% } \\
\text { dry weight }\end{array}$ \\
\hline & & & & \\
\hline \multirow[t]{13}{*}{ Series 4} & & 28 & $7 \cdot 28$ & \\
\hline & & 29 & 9.52 & \\
\hline & & 30 & $10 \cdot 76$ & \\
\hline & & $3 \mathrm{I}$ & II I I 6 & \\
\hline & & 32 & 12.45 & \\
\hline & & 33 & 15.20 & \\
\hline & & 34 & $I 8 \cdot I 2$ & \\
\hline & & 35 & I9.6I & \\
\hline & & 36 & $2 \mathrm{I} \cdot 74$ & \\
\hline & & 37 & 24.83 & \\
\hline & & 38 & 27.06 & \\
\hline & & 39 & $34 \cdot 27$ & \\
\hline & & 40 & $35 \cdot 37$ & \\
\hline May 27 & Otter Spit & $35 \cdot 4$ & $19 \cdot 36$ & $5 \cdot 7$ \\
\hline \multirow[t]{2}{*}{ " 30} & Otter Spit & $36 \cdot 7$ & $2 \mathrm{I} \cdot 03$ & $8 \cdot 5$ \\
\hline & & $\begin{array}{l}37 \cdot 0 \\
37 \cdot 2\end{array}$ & $\begin{array}{l}2 \mathrm{I} \cdot 88 \\
23 \cdot 15\end{array}$ & \\
\hline \multirow[t]{9}{*}{ Series 5} & & 33 & 15.80 & \\
\hline & & 34 & I 6.23 & \\
\hline & & $\begin{array}{l}35 \\
26\end{array}$ & $\begin{array}{l}18.65 \\
20.46\end{array}$ & \\
\hline & & $\begin{array}{l}30 \\
37\end{array}$ & $24 \cdot 36$ & \\
\hline & & 38 & 28.73 & \\
\hline & & 39 & 34.21 & \\
\hline & & 40 & $37 \cdot 4 \mathrm{I}$ & \\
\hline & & $4 \mathrm{I}$ & 43.66 & \\
\hline & & $\begin{array}{l}42 \\
43\end{array}$ & $\begin{array}{l}48 \cdot 67 \\
52 \cdot 87\end{array}$ & \\
\hline \multirow{2}{*}{$\begin{array}{c}\text { June } 5 \\
, \quad 17\end{array}$} & Otter Spit & $35 \cdot 7$ & $3 I \cdot I 5$ & 4.9 \\
\hline & Barmore & 49 & $94 \cdot 6$ & - \\
\hline
\end{tabular}

For an experiment on oxygen consumption, larvae were obtained from spawn which was dredged on the Iron Rock Ledges and hatched in the laboratory. Hatching had taken place over the previous five days and the length of the fifty larvae used varied from 5.5 to Io $\mathrm{mm}$. (average size $8.3 \mathrm{~mm}$.). A few had lost the yolk-sac and its size varied considerably in the others. Larval herring taken on the Iron Rock Ledges on the previous day whose average size was $7.8 \mathrm{~mm}$. weighed on an average $0.20 \mathrm{mg}$.

Thirty herring were put in each of four bottles of filtered sea water of which two were kept in the dark (at $10^{\circ} \mathrm{C}$.) and two in sunlight (at $8-12^{\circ} \mathrm{C}$.) for $6 \mathrm{hr}$. The initial oxygen content of the bottles was $6.6 \mathrm{ml}$. per litre. Those in the dark used 0.46 and $0.44 \mathrm{ml}$. per I000 per $\mathrm{hr}$. and those in the light 0.40 and $0.33 \mathrm{ml}$. per $1000 \mathrm{per} \mathrm{hr}$. A control experiment showed that there was not enough phytoplankton in the filtered sea water to affect the results either in the dark or in the light.

Larvae from the same source were used for another respiration experiment I9 days later, but used only 0.25 and $0.21 \mathrm{ml}$. per Iooo per hr. The yolk-sac 
had completely disappeared, the size ranged from 9.5-II mm., and the weight was only $0.12 \mathrm{mg}$. per herring as compared with $0.3 \mathrm{I} \mathrm{mg}$. for herring in the sea about the same time. As is shown in Table VI herring even in the yolk-sac stage in the sea weigh more than this (0.186 mg.). This experiment showed that the artificially reared herring were not now growing normally.

The larvae used in the first respiration experiment were afterwards used to determine the lethal temperature. Five herring were put in each of ten small bottles and these were kept in a tank whose temperature was controlled by a thermostat. The temperature at the beginning of the experiment was $\mathrm{II}^{\circ} \mathrm{C}$. At the end of each hour the condition of the herring was noted and the temperature then raised by $\mathrm{I}^{\circ} \mathrm{C}$.

With the increase of temperature, activity increased up to $23^{\circ} \mathrm{C}$. after which they became sluggish or moribund. At $26^{\circ} \mathrm{C}$. five bottles were taken out of the tank and allowed to cool. The remaining five bottles were raised to $27^{\circ} \mathrm{C}$. After an hour at this temperature all the herring with one exception were moribund. They were then allowed to cool. By next morning, of those removed at $26^{\circ} \mathrm{C}$. practically all had recovered and of those removed at $27^{\circ} \mathrm{C}$. about half had recovered. The results indicate that larval herring are affected by a temperature above $24^{\circ} \mathrm{C}$. but could survive, for at least a short time, a temperature of $26^{\circ} \mathrm{C}$. Gross (I937) has suggested that larval herring are very susceptible to sudden change of temperature, but the above results do not seem to confirm this.

The oxygen content of one of the bottles at $27^{\circ} \mathrm{C}$. was $5.13 \mathrm{ml}$. per litre showing that lack of oxygen can not have affected the results.

We are indebted to the Fishery Board for Scotland who arranged the forwarding of weekly reports on the Clyde herring fishery, and to $\mathrm{Mr} \mathrm{H}$. J. Buchanan-Wollaston who helped us with the statistical work. We also wish to thank the crew of the Nautilus for their constant help in the collection of the material.

\section{SUMMARY}

I. Samples of herring from the Clyde sea-area were obtained weekly from the time of hatching in March until metamorphosis in June.

2. The rate of growth was regular, about $3 \mathrm{~mm}$. in length per week; the development was similar to that described from elsewhere.

3. The herring which hatched off the south-west of Arran gradually moved northwards into the mouth of Loch Fyne and remained there until metamorphosis.

4. The proportion feeding was usually small. The food consisted mainly of copepods, both young stages and adults. The size of the food organisms eaten depended roughly on the size of the herring. 
5. Plankton hauls taken at the same time as herring were captured showed that there was a general relationship between plankton and gut contents.

6. The relationship of the dry weight $(W)$ of the herring to the length $(L)$ is given by the equation $W=0.0000020 L^{4 \cdot 52}$. The fat content was low but increased as the fish approached metamorphosis.

7. The oxygen consumption of herring larvae reared in the laboratory was measured. These larvae did not tolerate a temperature above about $26^{\circ} \mathrm{C}$.

\section{REFERENCES}

Clark, R. S., I933. Herring larvae. The mixing of the broods in Scottish waters. Rapp. Proc. Verb. Cons. Int. Explor. Mer, Vol. Lxxxv, Part 3, pp. II-I8.

Fulton, T. W., I904. The rate of growth of fishes. 22nd Ann. Rep. Fish. Bd. Scotland, Sci. Invest., pp. I4I-24I.

- I906. On the growth and age of the herring (Clupea harengus). 24th Ann. Rep. Fish. Bd. Scotland, Sci. Invest., pp. 293-342.

Gross, F., I937. Notes on the culture of some marine plankton organisms. Fourn. Mar. Biol. Assoc., Vol. xxI, pp. 753-68.

Hardy, A. C., I924. The herring in relation to its animate environment. Part I. The food and feeding habits of the herring with special reference to the east coast of England. Min. Agric. Fish., Fish. Invest., Ser. II, Vol. viI, No. 3, pp. I-53.

Lebour, M. V., I92I $a$. The larval and post-larval stages of the pilchard, sprat and herring from the Plymouth district. Fourn. Mar. Biol. Assoc., Vol. xII, pp. 427-57.

- I92 I $b$. The food of young clupeoids. Fourn. Mar. Biol. Assoc., Vol. XII, pp. 458-67. 1924. The food of young herring. Fourn. Mar. Biol. Assoc., Vol. xiII, pp. 325-30.

- 1933. The importance of larval mollusca in the plankton. Fourn. Cons. Int. Explor. Mer, Vol. viII, pp. 335-43.

Masterman, A. T., I896. Note on the rate of growth, larval and post-larval forms of the herring. I4th Ann. Rep. Fish. Bd. Scotland, Sci. Invest., pp. 294-302.

MeYer, H. A., I878. Beobachtungen über das Wachsthum des Herings im westlichen Theile der Ostsee. Fahresbericht der Komm. z. wiss. Untersuch. der deutschen Meere in Kiel, 4-6. Jahrg., pp. 227-252.

OgILvie, H. S., I927. Observations on the food of the post-larval herring from the Scottish coast. Fisheries, Scotland, Sci. Invest., No. I, pp. I-Io.

Runnstr $\varnothing$ M, S., I934. The pelagic distribution of the herring larvae in the Norwegian waters. Rapp. Proc. Verb. Cons. Int. Explor. Mer, Vol. Lxxxvin, No. v, pp. I-6.

Russell, F. S., I930. The vertical distribution of marine macro-plankton. IX. The distribution of the pelagic young of teleostean fishes in the daytime in the Plymouth area. Fourn. Mar. Biol. Assoc., Vol. xvi, pp. 639-76.

Stoddard, J. L. \& DruRy, P. E., I929. A titration method for blood fat. Fourn. Biol. Chem., Vol. 84, pp. 74I-48.

Williamson, H. C., I910. Experiments to show the influence of cold in retarding the development of the eggs of the herring (Clupea harengus, L.), plaice (Pleuronectes platessa, L.) and haddock (Gadus aeglefinus, L.). 27th Ann. Rep. Fish. Bd. Scotland, Part III, Sci. Invest., pp. Ioo-28.

- I9II. Report on the retardation of the development of the ova of the herring. Fisheries, Scotland, Sci. Invest., I9I0, No. II, pp. I-I2. 